\title{
Political Sophistication and Presidential Candidate Considerations: Disentangling the Effects of Knowledge,
} Interest, and Media Exposure

\author{
Jeff R. DeWitt
}

Answers to political sophistication questions are typically tied to theoretical or normative assumptions, which produce given sets of operational guidelines. In this study, I develop an understanding of election specific expertise, conceived of as three distinct dimensions - knowledge, interest, and media exposure. This methodological approach helps provide a richer appreciation of the unique effects of each dimension on the nature, number, and breadth of candidate considerations employed by voters. Results lend support for the overriding claim that sophistication is a critical source of heterogeneity within the American electorate. The classic democratic competency standard of an issue-driven voting public is achieved through a more knowledgeable, interested citizenry. At the same time, knowledge and interest produce divergent influences on particular types of personality-based candidate evaluations while media exposure is most remarkable for its absence of explanatory value.

Scholars have long noted how the American public falls short of the classic democratic ideal-the normative benchmark of an issue-focused, ideologically-driven citizenry. Evidence indicates that people are largely unsophisticated about political issues and candidates' public policy positions, and this reality may have become appreciably more pronounced over the past few decades (Delli Carpini and Keeter 1991; Bennett 1995; PEW Research Center 2007). At the same time, personality-based electoral judgments, especially those relating to candidate competence and character, have become dominant. Public opinion polls question respondents about which presidential contender they would most like to flip burgers with at a backyard barbecue, share a beer with at the local pub, have as a teacher, and ask for advice. ${ }^{1}$ Although it is undeniable that the mass-mediated information environment has propelled the personalization of politics, and individual political judgments are often derived from incomplete data and mostly through constrained cognitive processes, we are far from understanding the impact of political sophistication during presidential election campaigns.

To date, public opinion research has produced contradictory findings. Some observers have concluded that "if political psychologists know anything, they know that political sophistication matters." (Rahn 1994, 12; see also McGraw and Lodge 1996; Fiske and Kinder 1981; Fiske et al. 1983; McGraw and Pinney 1990; Fiske et al. 1990). Sophisticates think

JefF R. DeWITt is Associate Professor of Political Science at Kennesaw State University.

The American Review of Politics, Vol. 33, Winter, 2012-2013: 271-293

(C)2012 The American Review of Politics 
about candidates differently than novices do in that they tend to identify more meaningful patterns in information, encode information in broader, more abstract ways, and process information in a more complex fashion. Depending on level of sophistication, voters employ different judgmental criteria (Sniderman et al. 1991; Rivers, 1988; Gomez and Wilson 2001; Gomez and Wilson 2006). Individuals with more sophistication put more weight on issue positions and policy differences while those on the lower end of the sophistication scale pay more the attention to the candidates' personality traits (Converse 1964; Knight 1985; Sniderman et al. 1991). Other studies have shown that sophisticates are actually more likely to base assessments on the candidates' personality characteristics as opposed to perceived issue differences (McGraw and Steenbergen 1995; Miller et al. 1986; Lau 1989; Glass 1985) or sophistication is inconsequential with regard to candidate evaluations (Rahn et al. 1990; Graber 1984; Just et al. 1996). Vast assortments of judgmental categories are available to and used by a wide and diverse range of voters. "It is virtually impossible to categorize individuals as party voters, issue voters, personal voters and so forth . . . individuals have a wide assortment of information about the candidates that they try to integrate into a meaningful whole" (Just et al. 1996, 218). As such, the key question remains unanswered. Are there systematic differences in the way sophisticated and unsophisticated voters consider presidential candidates?

In this study, I employ National Election Study data from six presidential elections (1984-2004) in order to assess the influence of political sophistication on the nature, number, and breadth of candidate considerations employed by voters. I develop an understanding of election specific expertise, or sophistication as related to elections in general and as a reflection of engagement in the information flow that surrounds the particular contest at hand. Sophistication is thus conceived of as three inter-related yet distinct dimensions, including political knowledge of the relative positions of candidates and parties, political interest in and attention to the unfolding campaign, and media exposure to political news. A multidimensional measurement approach helps provide a more nuanced understanding of how each dimension may produce significant and unique consequences for different types of presidential candidate considerations while also generating deeper and richer evaluative content.

\section{An Election-Specific Understanding of Political Sophistication}

Answers to political sophistication questions are often tied to theoretical or normative assumptions, which produce given sets of operational guidelines. Early voting studies promoted the ability of individuals to think ideologically and consistently about public policy issues as the preeminent 
yardstick when evaluating candidates for political office (Campbell et al. 1960; Converse 1964). Much time was spent lamenting the ill-informed, uninterested, incompetent citizenry (Berelson et al. 1954; Campbell et al. 1960; Converse 1964; Converse and Markus 1979). Political choices seemed to be "matters of sentiment and disposition rather than reasoned preferences" (Berelson et al. 1954, 311). Follow-up research, which assessed the "changing" and "new" American voter, while often critical of Campbell and Converse's conclusion, also subscribed to the lexical status of an issue-focused, ideologically-driven citizenry (Nie et al. 1976; Smith 1989).

In the past few decades, scholars have set sights on a "more fully developed and independent measure" (Neuman 1986, 51) and called for a more efficient "out of sample" understanding of political sophistication (Zaller 1990; Zaller 1992). Conventional reliance on knowledge measures often rest on assumptions about the type and amount of information competent citizens should possess and studies therefore focus on whether the public measures up to some pre-determined normative standard. The shape of the distribution is the primary concern. For instance, Bennett $(1995,523)$ highlights the "intractability of political ignorance" while Delli Carpini and Keeter (1996, 69) conclude that "the American public, while not as politically informed as one might hope, is also not as uninformed as some characterizations have suggested." In the end, it is clear that, as Freedman et al. (2004, 723) point out, "saving democracy from the (informational) shortcomings of the American citizen has been an ongoing challenge for political science."

Political awareness and political knowledge indexes, such as recommended by Zaller (1992) and Delli Carpini and Keeter (1996), have proven to be "excellent general duty measures" that assess knowledge about public affairs and they may also serve as "valid indicators of other conceptually distinct concepts, such as political sophistication" (Price 1999, 607). This conceptual parsimony has prompted some observers to contend that we have moved toward a resolution of the sophistication question, with knowledge becoming the ascendant option (Price 1999). Other research, which this study builds on, strikes a cognitive psychological chord in proposing a multidimensional understanding of political sophistication, best considered as neither one proxy indicator nor as an all-encompassing construct but as a "constellation" of qualities, each relating to different facets of expertise (Krosnick 1990a). Fiske (1983) initially presented a "practical view of political expertise" comprised of an interlocking set of indicators including knowledge, interest and participation. McGraw and Pinney (1990) subsequently constructed a measure of "political sophistication" from knowledge, media use, and interest (see also Fiske et al. 1990; McGraw and Lodge 1996). Indeed, media exposure and political interest may have independent effects on candidate evaluations, wholly separate from any influence of political knowledge (Krosnick and Brannon 1993). ${ }^{3}$ 
Political sophistication, as conceived, is distinguishable from sophistication in the more general sense, which has served as the primary variable in studies of opinion formation and change (Zaller 1990), the distribution and depth of public knowledge (Delli Carpini and Keeter 1996), the effectiveness of individual political information processing (Fiske et al. 1990), and the relationship between exposure to news and learning (Rhee and Cappella 1997). In those cases, reliance on knowledge, reflected in an individual's ability to retrieve factual information from long-term memory, is valid on its face. This study is interested in electoral implications, which requires focus directly on sophistication "in use"; that is, its application by individual voters within the candidate evaluation process. Converse (1964, 212-213) initially emphasized the "active use" of "contextual knowledge" that a person possesses. Neuman's (1981) further developed this literature stream with a "knowledge in use" conceptual framework and Krosnick (1990b) validated domain-specific, as opposed to generalized, expertise. An expert, he argued, "is a person who is especially good at performance in some domain" (Krosnick 1990a, 3). As such, election-specific expertise denotes sophistication relating to the informational flow that surrounds a given presidential contest.

Each election produces a unique informational environment which interacts with individual incentive structures and thereby helps frame the judgmental process (Alvarez 1998) and induces "temporal heterogeneity" among the voting population (Peterson 2005). The "high stimulus" nature of elections may dip "rather deeply into the less involved elements of the electorate" (Converse 1962, 584). Voters who may pay scant attention to current events and give little thought to political questions routinely tune in during presidential election seasons, inspired by the "uses and gratifications" (Ruggiero 2000) relating to civic duty which may be amplified by the wave of political information that surrounds them. Some people are enthralled with their choices in certain elections and not in others. By including salienceintensive indicators such as political interest and media exposure, we are better able to isolate the relationship between information and candidate assessments while emphasizing the environment in which electoral judgments are made in the first place.

While political sophistication may produce uneven influences on the types of candidate evaluations employed, it is reasonable to expect more consistently positive relationships in terms of impact on the depth and breadth of image content. Because certain voters are more interested in politics, more exposed to information, and more knowledgeable about the campaign, they should draw on more considerations, or "schemata." Sophisticated voters have a more expansive store of evaluative content represented in memory (McGraw and Steenbergen 1995; McGraw and Pinney 1990) and that content should be more accessible and easily activated than that of less 
sophisticated individuals (Lau and Sears 1986). A greater number of considerations should be brought to bear (Graber 1984; Neuman 1986; Sniderman et al. 1991) and sophisticates should have more diversity within their cognitive array, which will be reflected in more schematic categories (Graber 1984; Sniderman et al. 1991; Sniderman et al. 1990; Luskin 1990).

\section{Data, Concepts, and Measures}

In order to examine the relationship between various dimensions of political sophistication and candidate evaluations, this study pools crosssectional survey data compiled by the American National Election Study (NES) during presidential election years from 1984 through $2004 ;^{4}$ which represents a diverse assortment of information climates and electoral contexts since incumbents competed in four of these cycles and we had open seat contests in two cycles. The resulting dataset is comprised of 8566 cases in total. Variables are drawn from both pre-election and post-election waves. Key measures are described below and in the Appendix.

\section{Computing Political Sophistication}

I propose a multidimensional understanding of election-specific sophistication that involves a constellation of several qualities: political interest, media exposure, and political knowledge. Each variable is measured using a summative scale, with higher scores indicative of greater sophistication. In addition to raw index scores, each election year sample is trichotomized into low, middle, and high sophistication groupings based on the distribution of values for these scores. ${ }^{5}$ Respondents are therefore considered alongside others from the same campaign season, thus maintaining the electionspecific quality of the measure.

Political Knowledge refers to the degree to which an individual receives, comprehends, and is able to recall specific information about the political environment surrounding the presidential campaign. Knowledge is measured with a test that requires correct placement of the candidates and parties on issue and ideology scales plus one question relating to partisan control of the House of Representatives. Although some studies have highlighted weaknesses inherent in objective tests of general political knowledge, such a measurement approach is commonly employed (see, e.g., Luskin 1987; Fiske et al. 1990; Zaller 1990; Zaller 1992; Brians and Wattenberg 1996; Goren 2004; Holbrook 2006; Claassen and Highton 2009). ${ }^{6}$ Direct measures of knowledge are especially useful in that they require minimal interpretation by investigators and are not vulnerable to problems that may plague self-report items. Either the respondent correctly answers a 
question or he/she does not. ${ }^{7}$ The knowledge index was subjected to reliability testing and demonstrates significant internal consistency, producing an alpha score of .83 .

Political Interest refers to the degree to which an individual is motivated to seek out political information and pay attention to news about the political campaign. This measure reflects political sophistication in that interest denotes cognitive engagement and a tendency to think more seriously about the information to which one is exposed (Rhee and Cappella 1997). As such, we should expect a more focused level of reasoning from voters who feel more invested in the election outcome. Interest scores are compiled from three self-report measures: pre and post election attention to the campaign and the degree to which the respondent follows politics. Indicators are scaled to $0-1$ and scores are summed to produce overall interest values, ranging from $0-3$. Setting aside measurement-related concerns relating to socially desirable response tendencies, ${ }^{8}$ the interest index demonstrates acceptable reliability, with an alpha of .79.

Media Exposure refers to the degree to which an individual is exposed to information through the mass media (television and newspapers) during the campaign season. Voters are more sophisticated about politics, albeit in a more latent sense, if they read and watch the news even if such information is not always "received." The power of the media to persuade and shape evaluative content is one of the most thoroughly chronicled theories in the realm of public opinion (Iyengar and Kinder 1987; Just et al. 1996; Lodge et al. 1995; Miller and Krosnick 2000). Media output helps influence the standards by which political objects are judged. Television and newspaper scores are produced based on self-reports of the number of days an individual is exposed to that media in the past week. For consistency, each item is scaled to $0-1$ and combined to create a total exposure score ranging between $0-2$.

Finally, while not part of political sophistication as formally conceived, education is a variable of special interest. One's knowledge about politics is closely connected to education level (Campbell et al. 1960; Price 1999; Delli Carpini and Keeter 1996; Fiske et al. 1990) and some research has even used education as a proxy measure for sophistication (Krause 1997; Miller et al. 1986; Converse 1975). At the very least, research reveals strong relationships among education, political knowledge, and reception of new information, which produce "knowledge gaps" between the better and less welleducated segments of the population. ${ }^{10}$ Formal education, measured with a five-point scale from less than high school to graduate degree, provides an important intellectual foundation for cognitive engagement but that is relatively static and concrete. Election-specific political sophistication, on the other hand, is largely the product of an interaction between personal incen- 
tive structures and the prevailing informational environment, a dynamic which may serve to mediate the effective influence of education on individual attitudes (Prior 2005; Jerit et al. 2006).

\section{Computing Candidate Considerations}

Moving to the other side of the causal arrow, the measurement of presidential candidate images inevitably requires an assessment of the cognitive content in the voter's head. Prevailing images are compartmentalized into substantive trait dimensions, or considerations, which naturally vary from voter to voter and candidate to candidate. A half-century ago, it was made clear. "The point is simply that 'attractive' implies more than something about the candidate himself; it also implies something about the response dispositions of the electorate" (Stokes 1966, 25).

In order to compute candidate considerations, I expand on Zaller's (1992) conceptual definition to incorporate "any reason that might induce an individual to decide a political issue (or evaluate political candidates) one way or the other" (Zaller 1992, 40; italics mine) and employ responses to the battery of open-ended survey questions which invite voters to express "likes" and "dislikes" about the presidential candidates. ${ }^{11}$ Some scholars are critical of open-ended items. ${ }^{12}$ Others have presented evidence for the clustering of survey responses into broad schematic categories and defended them as the most valid indicators of evaluative content since they allow people to define and articulate their own "issue space," expressing whatever impressions come to mind in reference to political objects (Repass 1971, 391; Geer 1991). Numerous studies have mined the content of these openended responses for the purpose of describing differences in candidate evaluations (see, e.g., Lau 1986; Lau 1989; Neuman 1986; DeSart 1995; Kessel 2004; Kessel and Weisberg 1999; Holbrook 2006). Given the accessibility bias associated with more salient political judgments, this study employs a weighting scheme that affords appropriate heft to each consideration offered based on the order of response.

I rely on investigators' initial coding, which are detailed in National Election Study documentation, and employ four conventional groupings that represent the basic elements of American politics: issues, parties, groups and personalities (Lasswell 1936; Lau 1986; Lau 1989). Issue references are those that associate the candidates with policy positions. These may refer to substantive areas of governance such as the environment, foreign relations, government spending, taxes, health, social, or "law and order" policies. Issue considerations may also be more general or philosophical in nature, such as references to liberal or conservative ideological positioning of the candidates. Party criteria reference the candidates' party affiliations; that is, they 
are evaluated in terms of their partisan affiliations rather than as independent electoral contenders. Group references include those that allude to political, social, or regional group loyalties of the candidates. A miscellaneous category was created for considerations that do not fit into the other groupings, including references to unique campaign events, and are not part of the analyses.

In addition, anticipating a wide assortment of personality-based judgments, I provide expanded categories for these responses. Sub-categories are structured based on studies by Miller et al. (1986) and Just et al. (1996) who parse personality evaluations into character, competence, and apolitical qualities. Character references include those relating to the candidates' integrity, honesty, sincerity, reverence for public service, political duty, and interpersonal qualities or deficiencies. Competency-based judgments relate to the candidates' ability to effectively govern and assessments regarding their administrative capabilities. Apolitical considerations refer to occupational background, family history, visual appearance, health, or age. In summary, consideration values that reflect the percentage of image content dedicated to the seven types of candidate considerations (issues, party, group, personality, character, competence, apolitical) for the major party presidential candidates are calculated for each respondent.

Mean scores for the types of candidate considerations employed, and corresponding standard deviation values, are presented in Table 1. Overall, personality content comprised 47 percentage of image content, followed by 39 percent for issues, 7 percent for party-references and 6 percent for groups.

Table 1. Types of Candidate Considerations, 1984-2004

\begin{tabular}{lcc}
\hline & $\bar{x}$ & s.d. \\
\hline Issue & 39 & 31 \\
Party & 07 & 16 \\
Group & 06 & 14 \\
Personality & 47 & 31 \\
$\quad$ Character & 14 & 19 \\
$\quad$ Competence & 18 & 22 \\
$\quad$ Apolitical & 11 & 17 \\
N & & 8566 \\
Notes: Cell values in the above table represent the average percentage of candidate image that cor- \\
esponds with that type of candidate consideration and corresponding standard deviation values. \\
Columns do not total 100 percent because miscellaneous considerations and those without specific \\
elaboration regarding the specific bases of judgment are excluded from analyses and not presented. \\
\hline
\end{tabular}


Regarding personality-specific considerations, 18 percent emphasized the candidate competence while 14 percent highlighted character-relevant judgments and 11 percent was apolitical.

\section{Findings}

\section{Sophistication and the Nature of Candidate Considerations}

In the following sections, I present descriptive analyses and results from a series of multivariate OLS models that examine the impact of various dimensions of political sophistication on presidential candidate considerations offered by voters. Table 2 displays the evaluative criteria used in presidential elections from 1984-2004, according to political sophistication. ${ }^{14}$ Several interesting findings emerge. First, both political interest and political knowledge were associated with a more intensive focus on the candidates' issue positions. For those at the medium and high interest level 39 percent of image content was dedicated to policy while it comprised 36 percent for those at the lowest interest level. This positive relationship follows a more linear pattern for political knowledge, as issues comprised 42 percent of candidate images for those at the high level, 38 percent for those at the medium level, and 35 percent for those at the low level. On the other hand, personality-based judgments were less common for the most knowledgeable voters, as they comprised half of image content for those least knowledgeable and 45 percent for those most knowledgeable. Political interest is negatively associated with party-based candidate criteria while media exposure is associated with fewer issue judgments and a heightened focus on the candidates' personal qualities.

The next step is to determine how descriptive results hold up in multivariate OLS regression models. NES data from the six presidential elections were pooled, with dummy variables representing the contextual, fixed effects surrounding each individual election year. Separate stand-alone models were tested with dependent variables representing the percentage image content dedicated to each of the four general evaluative categories and three personality-specific categories. Index scores reflecting the respondents' degree of political interest, exposure to the media, and political knowledge served as the principle independent variables. Controls included relevant demographic (education, age, gender, and race) and political (ideological and partisan strength) factors and a variable that represents the number of days prior to Election Day that the respondent was interviewed.

Findings presented in Table 3 mostly echo those in Table 2. Political interest significantly increases the use of issue-based judgments $(b=1.69)$. Political knowledge likewise increases issue content, whereby a one point 
Table 2. Types of Candidate Considerations by Dimension of Sophistication, 1984-2004

\begin{tabular}{|c|c|c|c|c|c|c|c|c|c|}
\hline \multirow{3}{*}{$\begin{array}{l}\text { Type of } \\
\text { Consideration }\end{array}$} & \multicolumn{9}{|c|}{-Dimension of Political Sophistication- } \\
\hline & \multicolumn{3}{|c|}{-Interest-_ } & \multicolumn{3}{|c|}{ - Exposure- } & \multicolumn{3}{|c|}{ Knowledge } \\
\hline & Low & Med & High & Low & Med & High & Low & Med & High \\
\hline Issue & 36 & 39 & 39 & 40 & 40 & 35 & 35 & 38 & 42 \\
\hline Party & 08 & 07 & 06 & 08 & 07 & 08 & 08 & 08 & 06 \\
\hline Group & 06 & 06 & 06 & 06 & 06 & 06 & 06 & 06 & 05 \\
\hline Personality & 48 & 47 & 48 & 46 & 47 & 50 & 50 & 47 & 45 \\
\hline Character & 15 & 14 & 15 & 14 & 14 & 15 & 13 & 14 & 15 \\
\hline Competence & 17 & 18 & 19 & 17 & 18 & 19 & 19 & 18 & 18 \\
\hline Apolitical & 12 & 11 & 11 & 11 & 11 & 12 & 13 & 12 & 09 \\
\hline $\mathrm{N}$ & 2062 & 4029 & 2475 & 1977 & 4137 & 2267 & 1954 & 4212 & 2400 \\
\hline
\end{tabular}

increase on the knowledge test produces nearly seven percentage points more policy-based judgments. In the end, voters who are more interested in and knowledgeable about the electoral contest most closely approximate the classic democratic ideal of issue-focused citizens. Political interest decreases party references $(b=-1.43)$. In fact, among all variables in the model, interest produces the greatest impact on party-based criteria. Political knowledge, on the other hand, decreases voter emphasis on the candidates' personality attributes, and does so to a similar degree as it increases issues $(b=-6.16)$, a finding which confirms much of the existing literature. Media exposure is most remarkable for its failure to provide any explanatory value. In no way does self-reported exposure to mediated information alter the general types of presidential candidate evaluations used by voters.

Table 4 expands on the electoral effects of political sophistication by presenting findings from regression models which predict the three types of personality-based consideration content (i.e., those that reflect the candidates' character, competence, and apolitical traits). While previous results indicated that interest in the campaign produced no significant effect on personality judgments in general, heightened interest does intensify focus on the candidates' professional competency in particular $(b=.86)$. Political knowledge, on the other hand, increases character-based judgments $(b=$ $2.45)$ and decreases those rooted in competence $(b=-3.46)$ and apolitical attributes such as physical appearance and age $(b=-3.57)$. Media exposure 


\section{Table 3. The Impact of Political Sophistication on the Types of Candidate Considerations}

\begin{tabular}{|c|c|c|c|c|}
\hline Independent Variables & $\begin{array}{l}\text { Issue } \\
\text { Model }\end{array}$ & $\begin{array}{l}\text { Party } \\
\text { Model }\end{array}$ & $\begin{array}{l}\text { Group } \\
\text { Model }\end{array}$ & $\begin{array}{l}\text { Personality } \\
\text { Model }\end{array}$ \\
\hline Constant & $\begin{array}{l}55.24 * * * \\
(1.98)\end{array}$ & $\begin{array}{l}7.97 * * * \\
(1.04)\end{array}$ & $\begin{array}{c}15.34 * * * \\
(.90)\end{array}$ & $\begin{array}{l}20.49^{* * *} \\
(2.00)\end{array}$ \\
\hline Days Before & $\begin{array}{l}.05^{* *} \\
(.02)\end{array}$ & $\begin{array}{l}-.01 \\
(.01)\end{array}$ & $\begin{array}{l}.03 * * * \\
(.01)\end{array}$ & $\begin{array}{l}-.07 * * \\
(.02)\end{array}$ \\
\hline Presidential Approval & $\begin{array}{l}-.10^{* *} \\
(.21)\end{array}$ & $\begin{array}{l}-.15 \\
(.11)\end{array}$ & $\begin{array}{c}-1.00 * * * \\
(.09)\end{array}$ & $\begin{array}{l}1.39 * * * \\
(.21)\end{array}$ \\
\hline Education & $\begin{array}{l}-1.63 * * * \\
(.31) \\
-.07\end{array}$ & $\begin{array}{c}.07 \\
(.16) \\
.01\end{array}$ & $\begin{array}{l}-.89 * * * \\
(.14) \\
-.08\end{array}$ & $\begin{array}{l}2.51 * * * \\
(.31) \\
.10\end{array}$ \\
\hline Interest & $\begin{array}{l}1.69 * * * \\
(.49) \\
.05\end{array}$ & $\begin{array}{c}-1.43 * * * \\
(.26) \\
-.08\end{array}$ & $\begin{array}{l}-.02 \\
(.22) \\
-.01\end{array}$ & $\begin{array}{l}-.20 \\
(.50) \\
-.01\end{array}$ \\
\hline Exposure & $\begin{array}{l}-.16 \\
(.62) \\
-.01\end{array}$ & $\begin{array}{l}-.26 \\
(.33) \\
-.01\end{array}$ & $\begin{array}{c}.44 \\
(.28) \\
.02\end{array}$ & $\begin{array}{l}-.14 \\
(.63) \\
-.01\end{array}$ \\
\hline Knowledge & $\begin{array}{l}6.81 * * * \\
(1.35) \\
.07\end{array}$ & $\begin{array}{c}-1.00 \\
(.71) \\
-.02\end{array}$ & $\begin{array}{l}.27 \\
(.61) \\
.06\end{array}$ & $\begin{array}{l}-6.16^{* * *} \\
(1.37) \\
-.06\end{array}$ \\
\hline Adjusted $\mathrm{R}^{2}$ & .07 & .06 & .09 & .09 \\
\hline $\mathrm{N}$ & 7392 & 7392 & 7392 & 7392 \\
\hline
\end{tabular}

again offers minimal explanatory value, producing no statistically significant effects on personality criteria.

Two additional findings presented in Tables 3 and 4 warrant attention. First, note that education negatively impacts issues $(b=-1.63)$ and positively influences personality $(b=2.51)$. The more educated a person is the less he evaluates presidential candidates in terms of their substantive policy positions and the more he is driven by the candidates' personality qualities and deficiencies. These results stand in contrast to findings presented earlier regarding political knowledge and suggest that formal education and election-relevant expertise are quite distinct from one another in terms of their electoral impact. 
Table 4. The Impact of Political Sophistication on the Types of Personality-Based Consideration Content

\begin{tabular}{|c|c|c|c|}
\hline Independent Variables & $\begin{array}{c}\text { Character } \\
\text { Model }\end{array}$ & $\begin{array}{c}\text { Competence } \\
\text { Model }\end{array}$ & $\begin{array}{l}\text { Apolitical } \\
\text { Model }\end{array}$ \\
\hline Constant & $\begin{array}{c}2.39 \\
(1.29)\end{array}$ & $\begin{array}{c}3.27^{*} \\
(1.41)\end{array}$ & $\begin{array}{l}9.89 * * * \\
(1.14)\end{array}$ \\
\hline Days Before & $\begin{array}{l}-.07 * * * \\
(.01)\end{array}$ & $\begin{array}{l}-.02 \\
(.01)\end{array}$ & $\begin{array}{c}.01 \\
(.01)\end{array}$ \\
\hline Presidential Approval & $\begin{array}{l}.03 \\
(.14)\end{array}$ & $\begin{array}{l}1.81^{* * * *} \\
(.15)\end{array}$ & $\begin{array}{l}-.08 \\
(.12)\end{array}$ \\
\hline Education & $\begin{array}{l}1.15^{* * * *} \\
(.20) \\
-.07\end{array}$ & $\begin{array}{l}1.13 * * * \\
(.22) \\
.07\end{array}$ & $\begin{array}{c}.40^{*} \\
(.18) \\
.03\end{array}$ \\
\hline Interest & $\begin{array}{c}-.06 \\
(.32) \\
.01\end{array}$ & $\begin{array}{c}.86^{*} \\
(.35) \\
.03\end{array}$ & $\begin{array}{l}-.43 \\
(.28) \\
-.02\end{array}$ \\
\hline Exposure & $\begin{array}{l}-.29 \\
(.40) \\
-.01\end{array}$ & $\begin{array}{l}-.24 \\
(.44) \\
-.01\end{array}$ & $\begin{array}{c}.38 \\
(.36) \\
.01\end{array}$ \\
\hline Knowledge & $\begin{array}{c}2.45^{* *} \\
(.88) \\
.04\end{array}$ & $\begin{array}{l}-3.46^{* * *} \\
(.97) \\
-.05\end{array}$ & $\begin{array}{l}-3.57 * * * \\
(.78) \\
-.06\end{array}$ \\
\hline Adjusted $\mathrm{R}^{2}$ & .06 & .05 & .03 \\
\hline $\mathrm{N}$ & 7392 & 7392 & 7392 \\
\hline
\end{tabular}

Second, the 'days before' variable, which captures the general effect of the unfolding informational environment, produces significant effects. As Election Day draws closer and the information stream grows deeper and richer, personality considerations, especially those relating to the candidates' character $(b=-.07)$, become more important to voters as issue criteria wane $(b=.05)$. The "personalization of politics" thesis is supported within the context of political information in presidential election campaigns (McAllister 2007). Over time, the public pays increasingly more attention to and learns more about the personality contest than policy differences.

A central overarching point is demonstrated with these models that deal with the nature of candidate considerations employed by voters. Their 
explanatory value, reflected in rather meager adjusted $\mathrm{R}^{2}$ values, is quite limited. This echoes V.O. Key's (1961) "holy ghost" claim ${ }^{15}$ in that the candidate evaluation process is largely idiosyncratic and not easily represented with formal modeling, especially when the specification seeks to parse candidate images into the particular trait dimensions that comprise them. In that respect, results provide support for those who argue that people are not easily classified according to the nature of their evaluative choices (see, e.g., Just et al. 1996). Nonetheless, even with the less-than-impressive $\mathrm{R}^{2}$ values and overwhelming fixed effects, individual sophistication variables emerge as statistically significant and contribute to our academic understanding.

\section{The Number and Breadth of Candidate Considerations}

The study now shifts to the relationship between sophistication and the number of considerations and consideration categories employed during the six presidential elections. Examinations of the depth and breadth of evaluative criteria are not uncommon. Delli Carpini and Keeter (1996) and Smith (1989) recommend counts of valid responses to open-ended questions as indicators of political knowledge while Jacobson (1981) utilizes a tally of responses to open-ended questions about congressional candidates in order to assess the relative richness of incumbent versus challenger evaluations. Similarly, Holbrook (2006) proposes a tally of the number of open-ended responses to capture the sheer volume of information stored in recalled memory. The focus here, however, is on how various dimensions of sophistication influence the number and categorical breadth of considerations volunteered responses are offered in the first place.

Table 5 presents average scores for the number of candidate considerations and consideration categories per candidate. Results indicate that each of the three dimensions of expertise is positively associated with the depth and breadth of image content employed by voters. People on the higher end of sophistication provided more responses from more judgmental categories. This relationship is the most pronounced for knowledge, whereby low sophisticates offered an average of 1.34 considerations per candidate from about three-fourths a category while those at the middle level offered an average of 2.42 considerations from 1.19 categories and those at the highest level provided an average of 3.5 overall considerations from nearly 1.45 categories. The trend is similar though less sharp for interest and even less so for media exposure dimensions, where the difference between low and high exposure amounts to less than one consideration and about one-third of a category. 
Table 5. Number of Considerations and Consideration Categories by Dimension of Sophistication, 1984-2004

\begin{tabular}{|c|c|c|c|c|c|c|c|c|c|}
\hline \multirow{3}{*}{$\begin{array}{l}\text { Type of } \\
\text { Consideration }\end{array}$} & \multicolumn{9}{|c|}{-Dimension of Political Sophistication- } \\
\hline & \multicolumn{3}{|c|}{ Interest } & \multicolumn{3}{|c|}{ Exposure- } & \multicolumn{3}{|c|}{-Knowledge- } \\
\hline & Low & Med & High & Low & Med & High & Low & Med & High \\
\hline Considerations & 1.42 & 2.44 & 3.33 & 1.87 & 2.53 & 2.71 & 1.34 & 2.42 & 3.50 \\
\hline Categories & .80 & 1.19 & 1.43 & .95 & 1.18 & 1.29 & .78 & 1.19 & 1.45 \\
\hline $\mathrm{N}$ & 2204 & 3750 & 2292 & 2032 & 3860 & 2155 & 2204 & 3750 & 2292 \\
\hline
\end{tabular}

In Table 6, I present findings from two final regression models, wherein dependent variables reflect the number of considerations and the number of consideration categories employed. As expected, political interest and political knowledge variables are significant across the board. Both interest in and knowledge about the campaign increase the number of considerations, as well as the number of consideration categories offered. Standardized coefficients indicate that they have roughly equal impact on the former while political interest has a slightly more pronounced impact on the latter. Education also generates significantly positive impact in both cases. Media exposure, the third dimension of political sophistication, once again falls short of statistically significant influence. Watching television or reading newspapers alone produces no independent effects on either the depth or breadth of candidate image content.

The more substantial $\mathrm{R}^{2}$ values for these models (.31 and .23) suggest superior data fit as compared to those relating to the nature of considerations. Political sophistication goes a long way to determining the sheer volume and density of image content people bring to bear when considering presidential candidates. Sophisticates, who are more interested and knowledgeable, are more engaged in the decision-making process and therefore use that information in order to expand the weight of their candidate images.

\section{Conclusion}

Since candidate images are the culmination of a voter's interaction with the political information environment during campaigns, it is imperative that researchers are clear on what denotes engagement with the communication flow in the first place. In this study, I offered a refined understanding of 


\section{Table 6. The Impact of Political Sophistication on the Number of Considerations and Consideration Categories, 1984-2004}

\begin{tabular}{lcc}
\hline Independent Variables & $\begin{array}{c}\text { Number of Considerations } \\
\text { Per Candidate }\end{array}$ & $\begin{array}{c}\text { Number of Categories } \\
\text { Per Candidate }\end{array}$ \\
\hline Constant & $.69^{* * *}$ & $.63^{* * *}$ \\
Days Before & $(.09)$ & $(.04)$ \\
& $-.01^{* * *}$ & $-.01^{* * *}$ \\
Presidential Approval & $(.01)$ & $(.01)$ \\
& $-.05^{* * *}$ & $-.03^{* * *}$ \\
Education & $(.01)$ & $(.01)$ \\
& $.23^{* * *}$ & $.06^{* * *}$ \\
Interest & $.02)$ & $(.01)$ \\
& .17 & .09 \\
Exposure & $.51^{* * *}$ & $.18^{* * *}$ \\
& $(.02)$ & $.01)$ \\
& .25 & .22 \\
Knowledge & .01 & .01 \\
& $(.03)$ & $.01)$ \\
Adjusted $\mathrm{R}^{2}$ & .01 & $.42^{* * *}$ \\
$\mathrm{~N}$ & $1.4^{* * *}$ & $(.03)$ \\
Notes: Cell entries are OLS regression coefficients with standard errors in parentheses. Standardized \\
coefficients are italicized. Controls for age, gender, race, partisanship, ideology, and election year \\
dummies are not presented. & $(.06)$ & .19 \\
& .26 & .23 \\
& .31 & 7939 \\
& 7875 & \\
& &
\end{tabular}

political sophistication that moves beyond distributional questions in order to direct the focus squarely onto the electoral consequences of political information. In doing so, I address a primary shortcoming of existing electoral sophistication research studies which too often rely on either political knowledge as the single cognitive moderator or an all-encompassing knowledge construct. A multidimensional approach is conceptually and methodologically preferable, especially when considering the role of information within the electoral context where candidate evaluations are made in the first place.

Findings presented in this study lend support for the overriding claim that political sophistication is a critical source of heterogeneity within the 
American electorate. When considered in multivariate models, both political interest and knowledge significantly shaped the content of presidential candidate evaluations in multiple directions. To no surprise, the classic democratic competency standard of an issue-driven electorate is achieved through a more engaged citizenry, as reflected in heightened interest in the campaign and election-specific political knowledge. Their candidate evaluations are more policy-focused and are drawn from a wider, deeper pool of considerations. Results also encourage a methodological distinction between formal education on the one hand and election-specific knowledge on the other.

This study is especially warranted given emerging trends. The political information environment is increasingly characterized by personality-driven coverage and personality-based electoral judgments have become dominant. While voters evaluate the candidates as people first (Peterson 2005), they differ in terms of the degree to which they emphasize personality-based judgmental criteria. Generally speaking, more knowledgeable voters are less drawn to the candidates' personal qualities and deficiencies. A closer look, however, reveals divergent effects on particular types of personality criteria. Voters who are more politically knowledgeable focus on candidate character, or the goodness of the person, while voters who are more politically interested focus on candidate competence, or the capability of prospective leaders.

Perhaps sophisticates simply pursue a more realistic, perhaps rational, approach to candidate evaluations. To them, it is not only the issues candidates promote but also the abilities they espouse and the faith they instill in voters that they will employ sound reasoning and judgment; they will follow through on whatever promises they make on the campaign trial. In the end, it boils down to whether people trust politicians to do the right thing. If that integral confidence standard which relates to trust in leadership, those "inner dispositions" of the candidates (Doherty and Gimpel 1997), is satisfied, the stage is set for voters to then consider specific questions of policies and issue positions.

Not only is candidate character more critical for more sophisticated voters, the data suggest the election-year dynamic of surging influence of character judgments. The closer to Election Day, the more important character criteria become. This may be explained as consequence of sheer timing, as thoughts about personal character naturally emerge to the forefront in voters' minds when the vote decision becomes more imminent. The increase in character judgments is also likely the product of campaign communication efforts to prime public opinion about these types of qualities and deficiencies.

Media exposure, on the other hand, produced minimal variability in terms of candidate considerations, as voters were neither more nor less likely 
to employ any particular type of candidate consideration based on that media exposure alone. Descriptive results revealed that people who read more newspapers and watched more news on television were more likely to offer personality-based judgments but this impact dissipated in the multivariate models. These null results amplify questions about the role of sheer media exposure in the formation of candidate images and raise methodological questions about self-report measures more generally. "Unfortunately, what seems perfectly obvious at face value does not always lend itself to ready empirical confirmation" (Mondak 1995, 159). The challenge has been ably enjoined by Barabas and Jerit (2009) who look beyond self-reported exposure and propose a natural experimental design that shifts focus onto the volume, breadth, and prominence of actual media coverage.

In conclusion, results produced in this study signal the need for more concerted investigations into the electoral impact of political sophistication on candidate images and highlight the importance of incorporating multiple, carefully considered sophistication measures. In addition, voters are certainly influenced by public policy issues when making personality-based candidate evaluations. In turn, particular issues are paramount only insofar as they resonate with voters and shape their assessments of the personal characteristics of the candidates. Further research should explore how the interactions of these judgmental criteria relate to the various dimensions of expertise.

\section{APPENDIX \\ Variables and Descriptions}

Age represents self-reported age on general election day.

Days Before represents the total number of days prior to Election Day that the preelection interview was conducted.

Education is a five-point education level scale, with 1 being no high school diploma and 5 being graduate degree.

Female is a dichotomous $(0-1)$ measure that represents being a female.

Ideological Strength is measured by folding the seven-point scale, producing values of 0 to 3 .

Media Exposure is calculated based on the number of days in the past week that the respondent reports watching television and reading the newspaper. Each item is scaled to 0 to 1 and combined to create an overall exposure score ranging from 0 to 2 .

Partisan Strength is measured by folding the seven-point scale, producing values of 0 to 3 . 


\section{APPENDIX (continued)}

Political Interest is calculated from the following three self-report measures: pre-election and post-election attention to the campaign and the degree to which the respondent follows politics. Responses for each indicator ("not very," "somewhat," and "very") are scaled from 0 to 1 and scores are summed to produce overall interest values, ranging from 0 to 3 .

Political Knowledge is calculated based on number of correct answers to a nine-item knowledge test, including the accurate placement of the presidential candidates on an aid to blacks scale, defense spending scale, ideology scale, job assurance scale, services / spending scale, and accurate placement of the parties on a defense spending scale, spending scale, an ideology scale, and correctly identifying which party has a majority of house members.

Presidential Approval is a dichotomous (0 for non-approval; 1 for approval) measure.

Race is a dichotomous ( 0 for non-white; 1 for white) measure.

\section{NOTES}

${ }^{1}$ The Quinnipiac Poll, published on May 26, 2004, gauged the candidates' "down to earth" qualities. Bass Beer Pub Polls" were commissioned during both the 2004 Democratic and Republican National Conventions, in Boston and New York, respectively.

${ }^{2}$ As is conventional, I use terms "sophistication" and "expertise" interchangeably throughout this article.

${ }^{3}$ Some observers who point to knowledge as most influential acknowledge that political sophistication is actually more than that single item (Fiske et al. 1990). Research also demonstrates the distinct causal connection between media exposure and political knowledge (Eveland et al. 2005).

${ }^{4}$ In 2008, the ANES adopted a new coding scheme for the battery of open-ended questions that serve as the foundation for my analyses.

${ }^{5}$ This three-tiered measurement approach approximates Neuman's (1986) "theory of political sophistication" which emphasizes a highly-stratified public with two generally defined inflection points - a group of "apoliticals" at the lowest level, the middle mass of "satisficers" and "sophisticates" at the highest level.

${ }^{6}$ This study adopts a conventional approach presented by Zaller's $(1990 ; 1992)$ "location tests" which are similar to "issue awareness" measures initially proposed by Patterson and McClure (1976). Nadeau and Niemi (1995) find that motivations and ability, together with contextual cues, help determine how respondents answer political knowledge questions and Mondak $(2000 ; 2001)$ demonstrates that political knowledge measures may be biased due to respondent traits and guessing tendencies.

${ }^{7}$ Correct responses are determined by relative placement, i.e. those that place the candidate or party at least one position to the left or to the right (in the appropriate direction) of the other candidate or party.

${ }^{8}$ Questions involving performance expectations, especially those rooted in democratic ideals are vulnerable to social desirability threats. Bishop et al. (1984) further 
demonstrate that question order can influence responses to questions about how much people think they follow what's going on in government and public affairs.

${ }^{9}$ Price and Zaller $(1993,134)$ caution against over-reliance on self-reported exposure measures and question their predictive validity because "[o]nly people who actually acquire information from the news can use it in forming and changing their political evaluations." Freedman et al. (2004) similarly distinguish between exposure and reception of information, with the former indicative of the physical encounter with a media message and the latter referencing the process "taking in" or comprehending the message. In this study, "awareness" or "reception" is effectively captured with the political knowledge test, which is independent of the exposure media measure.

${ }^{10}$ See Eveland and Scheufele (2000) for a review of educations and "knowledge gap" theory.

${ }^{11}$ The battery of open-ended questions, employed by the National Election Study since 1952, asks respondents "What would make you vote for (Presidential candidate)?" and "What would make you vote against (Presidential candidate)?" Respondents could provide up to five possible positive and five negative comments per candidate, resulting in up to twenty possible comments in total, except for 1992 and 1996 when comments for Perot were factored in. For more information on the data and coding, please refer to National Election Study documentation at http://www.electionstudies.org/.

${ }^{12}$ Rahn et al. (1994) suggest that responses may reflect post-hoc rationalizations of existing preferences. However, using latent variable structural equation models, Funk (1999) demonstrates the reliability of such a coding scheme.

${ }^{13}$ A similar logarithmic technique has been used by Miller et al. (1986), Lau (1989), and DeSart (1995). Responses are weighted inversely according to the order in which they were offered. For each survey participant, the first response to each question receives a weight of 5, the second receives a weight of 4 , etc. In order to control for respondent verbosity, relative percentages were achieved by dividing by the weighted total of all responses offered.

${ }^{14}$ Respondents who failed to offer any considerations are excluded from analyses relating to the nature of candidate considerations since with them no image content comparisons can be made.

${ }^{15}$ V.O. Key $(1961,8)$ famously said "[t]o speak with precision of public opinion is a task not unlike coming to grips with the Holy Ghost."

\section{REFERENCES}

Alvarez, R. Michael. 1998. Information and Elections, 2nd ed. Ann Arbor: University of Michigan Press.

Barabas, Jason, and Jennifer Jerit. 2009. Estimating the Causal Effects of Media Coverage on Policy-Specific Knowledge. American Journal of Political Science 53:73-89.

Bennett, Stephen Earl. 1995. Comparing American's Political Information in 1988 and 1992. Journal of Politics 57:521-532.

Berelson, Bernard, Paul Lazarsfeld, and William McPhee. 1954. Voting: A Study of Opinion of Formation in Presidential Campaigns. Chicago: University of Chicago Press.

Bishop, George F., Robert W. Oldendick, and Alfred J. Tuchfarber. 1984. What Must My Interest in Politics Be If I Just Told You 'I Don't Know'? Public Opinion Quarterly 48:510-519. 
Brians, Craig Leonard, and Martin P. Wattenberg. 1996. Campaign Issue Knowledge and Salience: Comparing Reception from TV Commercials, TV News, and Newspapers. American Journal of Political Science 40:172-193.

Campbell, Angus, Philip Converse, Warren Miller, and Donald Stokes. 1960. The American Voter. New York: Wiley.

Claassen, Ryan, and Benjamin Highton. 2009. Policy Polarization among Party Elites and the Significance of Political Awareness in the Mass Public. Political Research Quarterly 62:538-551.

Converse, Philip E. 1962. Information Flow and the Stability of Partisan Attitudes. Public Opinion Quarterly 26:578-599.

Converse, Philip E. 1964. The Nature of Belief Systems in Mass Publics. In Ideology and Discontent, ed. David E. Apter. New York: Free Press.

Converse, Philip E., and Gregory B. Markus. 1979. Plus Ça Change...: The New CPS Election Study Panel. American Political Science Review 73:32-49.

Converse, Philip E. 1975. Public Opinion and Voting Behavior. In The Handbook of Political Science, eds. Fred Greenstein and Nelson Polsby. Reading, MA: Addison-Wesley.

Delli Carpini, Michael, and Scott Keeter. 1991. Stability and Change in the U.S. Public's Knowledge of Politics. Public Opinion Quarterly 55:583-612.

Delli Carpini, Michael, and Scott Keeter. 1996. What Americans Know About Politics and Why It Matters. New Haven, CT: Yale University Press.

DeSart, Jay A. 1995. Information Processing and Partisan Neutrality: A Reexamination of theParty Decline Thesis. Journal of Politics 57:776-795.

Doherty, Kathryn, and James Gimpel. 1997. Candidate Character vs. the Economy in the 1992 Election. Political Behavior 19:177-196.

Eveland, William, and Dietram Scheufele. 2000. Connecting News Media Use With Gaps in Knowledge and Participation." Political Communication 17:215-237.

Eveland, William, Andrew Hayes, Dhavan Shah, and Nojin Kwak. 2005. Understanding the Relationship Between Communication and Political Knowledge. Political Communication 22:423-446.

Fiske, Susan T., and Donald R. Kinder. 1981. Involvement, Expertise, and Schema Use: Evidence from Political Cognition. In Personality, Cognition, and Social Interaction, eds. Nancy Cantor and John Kihlstrom. Hillsdale, NJ: L. Erlbaum Associates.

Fiske, Susan, Donald Kinder, and W. Michael Larter. 1983. The Novice and the Expert: Knowledge-Based Strategies in Political Cognition. Journal of Personality and Social Psychology 19:381-400.

Fiske, Susan, Richard Lau, and Richard Smith. 1990. On the Varieties and Utilities of Political Expertise. Social Cognition 8:31-48.

Freedman, Paul, Michael Franz, and Kenneth Goldstein. 2004. Campaign Advertising and Democratic Citizenship. American Journal of Political Science 48:723-741.

Funk, Carolyn. 1999. Bringing the Candidate into Models of Candidate Evaluations. Journal of Politics 6:700-720.

Geer, John. 1991. Do Open-Ended Questions Measure 'Salient' Issues? Public Opinion Quarterly 55:358-368.

Glass, David. 1985. Evaluating Presidential Candidates: Who Focuses on Their Personal Qualities. Public Opinion Quarterly 49:517-534.

Gomez, Brad, and J. Matthew Wilson. 2001. Political Sophistication and Economic Voting in the American Electorate: A Theory of Heterogeneous Attribution. American Journal of Political Science 45:899-914. 
Gomez, Brad, and J. Matthew Wilson. 2006. Cognitive Heterogeneity and Economic Voting: A Comparative Analysis of Four Democratic Electorates. American Journal of Political Science 50:127-145.

Goren, Paul. 2004. Political Sophistication and Policy Reasoning: A Reconsideration. American Journal of Political Science 48:462-478.

Graber, Doris. 1984. Processing the News. New York: Longman.

Holbrook, Thomas. 2006. Cognitive Style and Political Learning in the 2000 U.S. Presidential Campaign. Political Research Quarterly 59:343-352.

Iyengar, Shanto, and Donald Kinder. 1987. News That Matters: Television and American Public Opinion. Chicago: University of Chicago Press.

Jacobson, Gary. 1981. Incumbency Advantages in the 1978 Congressional Elections. Legislative Studies Quarterly 6:183-200.

Jerit, Jennifer, Jason Barabas, and Toby Bolsen. 2006. Citizens, Knowledge, and the Information Environment. American Journal of Political Science 50:266-282.

Just, Marion, Ann Crigler, Dean Alger, Timothy Cook, Montague Kern, and Darrell West. 1996. Crosstalk: Citizens, Candidates, and the Media in a Presidential Campaign. Chicago: University of Chicago Press.

Kessel, John, and Herbert F. Weisberg. 1999. Comparing Models of the Vote: The Answers Depend on the Questions. In Reelection 1996: How Americans Voted, eds. Herbert F. Weisberg and Janet M. Box-Steffensmeier. Chatham, NJ: Chatham House.

Kessel, John H. 2004. Views of the Voters. In Models of Voting in Presidential Elections, eds. Herbert F. Weisberg and Clyde Wilcox. Stanford: Stanford University Press.

Key, V. O., Jr. 1961. Public Opinion and American Democracy. New York: Knopf.

Knight, Kathleen. 1985. Ideology in the 1980 Election: Ideological Sophistication Does Matter. Journal of Politics 47:828-853.

Krause, George. 1997. Voters, Information Heterogeneity, and the Dynamics of Aggregate Economic Expectations. American Journal of Political Science 41:1170-1200.

Krosnick, Jon. 1990a. Conceptions of Expertise in Political Psychology. Social Cognition 8:1-8.

Krosnick, Jon. 1990b. Lessons learned: A Review and Integration of our Findings. Social Cognition 8:154-158.

Krosnick, Jon, and Laura Brannon. 1993. The Impact of the Gulf War on the Ingredients of Presidential Evaluations: Multidimensional Effects of Political Involvement. American Political Science Review 87:963-975.

Lasswell, Harold. 1936. Who Gets What, When, and How. New York: McGraw Hill.

Lau, Richard. 1989. Construct Accessibility and Electoral Choice. Political Behavior 11:5-31.

Lau, Richard R., and David O. Sears. 1986. Social Cognition and Political Cognition: the Past, the Present, and the Future. In Political Cognition: The 19th Annual Carnegie Symposium on Cognition, eds. Richard R. Lau and David O. Sears. Hillsdale, NJ: Erlbaum.

Lodge, Milton, Marco Steenbergen, Shawn Brau. 1995. The Responsive Voter Campaign Information and the Dynamics of Candidate Evaluation. American Political Science Review 89:309-326.

Luskin, Robert. 1987. Measuring Political Sophistication. American Journal of Political Science 31:856-899.

Luskin, Robert. 1990. Explaining Political Sophistication. Political Behavior 12:3331-3361. 
McAllister Ian. 2007. The Personalization of Politics. Pp. 571-588 in Oxford Handbook of Political Behavior, eds. Russell Dalton and Hans Dieter Klingemann. New York: Oxford University Press.

McGraw, Kathleen, and Milton Lodge. 1996. Political Information Processing: A Review Essay. Political Communication 13:131-142.

McGraw, Kathleen, and Neil Pinney. 1990. The Effects of General and Domain-Specific Expertise on Political Memory and Judgment Processes. Social Cognition 8:9-30.

McGraw, Kathleen, and Marco Steenbergen. 1995. Pictures in the Head: Memory Representation of Political Candidates. In Political Judgment: Structure and Process, eds. Milton Lodge and Kathleen M. McGraw. Ann Arbor: University of Michigan Press.

Miller, Arthur, Martin Wattenberg, Oksana Malanchuk. 1986. Schematic Assessments of Presidential Candidates. American Political Science Review 80:521-540.

Miller, Joanne, and Jon Krosnick. 2000. News Media Impact on the Ingredients of Presidential Evaluations: Politically Knowledgeable Citizens are Guided by a Trusted Source. American Journal of Political Science 44:301-315.

Mondak, Jeffrey J. 1995. Nothing to Read: Newspapers and Elections in a Social Experiment. Ann Arbor: University of Michigan Press.

Mondak, Jeffrey. 2000. Reconsidering the Measurement of Political Knowledge. Political Analysis 8:57-82.

Mondak, Jeffrey. 2001. Developing Valid Knowledge Scales. American Journal of Political Science 45:224-238.

Nadeau, Richard, and Richard Niemi. 1995. Educated Guesses: The Process of Answering Factual Knowledge Questions in Surveys. Public Opinion Quarterly 59:323-346.

Neuman, W. Russell. 1981. Differentiation and Integration: Two Dimensions of Political Thinking. American Journal of Sociology 86:1236-1268.

Neuman, W. Russell. 1986. The Paradox of Mass Politics: Knowledge and Opinion in the American Electorate. Cambridge, MA: Harvard University Press.

Nie, Norman H., Sidney Verba, and John Petrocik. 1976. The Changing American Voter. Cambridge, MA: Harvard University Press.

PEW Research Center. 2007. Public Knowledge of Current Affairs Little Changed by News and Information Revolutions. http://people-press.org/http://people-press.org/ files/legacy-pdf/319.pdf (September 14, 2011).

Patterson, Thomas, and Robert McClure. 1976. The Unseeing Eye: The Myth of Television Power in National Politics. New York: Putnam.

Peterson, David. 2005. Heterogeneity and Certainty in Candidate Evaluations. Political Behavior 27:1-24.

Price, Vincent. 1999. Political Information. In Measures of Political Attitudes, eds. John Robinson, Philip Shaver, and Laurence Wrightsman. New York: Academic Press.

Prior, Markus. 2005. News Vs. Entertainment: How Increasing Media Choice Widens Gaps in Political Knowledge and Turnout. American Journal of Political Science 49:577-592.

Rahn, Wendy, John Aldrich, Eugene Borgida, and John Sullivan. 1990. A Social-Cognitive Model of Candidate Appraisal. In Information and Democratic Processes, eds. John Ferejohn and James Kuklinski. Urbana: University of Illinois Press.

Repass, David. 1971. Issue Salience and Party Choice. American Political Science Review 65:389-400.

Rahn, Wendy. 1994. In Search of Unified Field Theories of Voting Behavior: Reconciling Political Psychology and Political Behavior Accounts. Paper presented at the National Election Study Conference on Candidate Evaluation, Berkeley, CA. 
Rhee, June Woong, and Joseph N. Cappella. 1997. The Role of Political Sophistication in Learning from News: Measuring Schema Development. Communication Research 24:197-233.

Rivers, Douglas. 1988. Heterogeneity in Models of Electoral Choice. American Journal of Political Science 32:737-757.

Ruggiero, Thomas E. 2000. Uses and Gratifications Theory in the 21st Century. Mass Communication \& Society 3:3-37.

Smith, Eric. 1989. The Unchanging American Voter. Berkeley: University of California Press.

Sniderman, Paul, Robert Griffin, and James Glaser. 1990. Information and Electoral Choice. In Information and Democratic Processes, eds. John Ferejohn and James Kuklinski. Urbana: University of Illinois Press.

Sniderman, Paul, Richard Brody, and Philip Tetlock. 1991. Reasoning about Politics: Explorations in Political Psychology. Cambridge: Cambridge University Press.

Stokes, Donald. 1966. Dynamic Elements of Contests for the Presidency. American Political Science Review 60:19-28.

Zaller, John. 1990. Political Awareness. Social Cognition 8:125-153.

Zaller, John. 1992. The Nature and Origin of Mass Opinions. Cambridge: Cambridge University Press. 